\title{
Energy efficiency of cacao agroforestry under traditional and organic management
}

\author{
David Pérez Neira ${ }^{1,2}$
}

Accepted: 28 July 2016/Published online: 5 September 2016

(C) INRA and Springer-Verlag France 2016

\begin{abstract}
The industrialization of agriculture has led to lower efficiency and greater dependence on non-renewable energy. Organic agriculture and traditional agriculture are thus potential alternatives. Cacao is a major crop in Ecuador. However, information on the energy efficiency and economic performance of Ecuadorian cacao in relation to the production management system is rare and basically inexistent in the case of organic management. Therefore, we studied here the energy and economic performance of the cacao production in the province of Guayas, Ecuador. Four types of management were identified in the province: traditional, semi-intensive, technified, and organic. On the basis of primary data, inputoutput and energy efficiency were estimated, with special attention given to the use of non-renewable energy and the monetary profitability of each management system. The total energy inputs of the different forms of management have been estimated at 3.04 for traditional, 12.47 for semi-intensive, 24.53 for technified, and $9.77 \mathrm{GJ} \mathrm{ha}^{-1}$ for organic. Irrigation, fertilization, and crop protection are the most important inputs for all four types of management, ranging between 85.7 and $97.7 \%$. The non-renewable external energy return on the investment (EROI) has been estimated at 1:2.93 for traditional, 1:1.85 for semi-intensive, 1:1.47 for technified, and 1:3.07 for organic. The different forms of management earned a net margin of 484 for traditional, 1051 for semi-intensive, 2323 for technified, and $\$ 1565 \mathrm{ha}^{-1}$ for organic. Our findings show that
\end{abstract}

David Pérez Neira

dpern@unileon.es; dapeneira@uvigo.es

1 Department of Applied Economy and Statistics, Leon University, Campus de Vegazana s/n, CP 24071 León, Spain

2 Ciencia Tecnología e Innovación de la República del Ecuador, Universidad Estatal de Milagro, Milagro, Ecuador the intensification of cacao production increases the net margin per hectare in relation to traditional cacao production, while it significantly reduces its non-renewable external EROI. Wellmanaged organic farms allow improving non-renewable external EROI by comparison with technified or semi-intensive management strategies, and it also improves the economic performance in relation to semi-intensive systems.

Keywords Energy analysis · Non-renewable energy · Sustainability $\cdot$ Organic agriculture $\cdot$ Production management $\cdot$ Economic analysis $\cdot$ Agroecology

\section{Introduction}

Agriculture industrialization has led to the intensification of energy use in agrarian systems, associated with an increase in the use of fertilizers, pesticides, herbicides, machinery, high-yield seeds/varieties, and an extension of irrigation (Leach 1976; Pimentel 1980). The increasing consumption and high dependence of agriculture on energy, especially non-renewable energy, are a clear symptom of unsustainability in food production systems and, thereby, of a lack of food sovereignty (Arizpe et al. 2011). In the last decades, one of the most important research lines has focused on analyzing to what extent the organic management of agroecosystems can be a more energy efficient alternative to conventional management (Smith et al. 2015). At the same time, several authors have shown the fundamental role played by traditional agriculture in the efficient use of energy (Funes-Monzote 2009; Altieri et al. 2011) and the conservation of natural resources and biodiversity (Gliessman 1998). Likewise, recent research works have proved how common practices in organic and traditional managements promoting the reuse of internal 
biomass (Tello et al. 2016) or animal-crop mutualism (Pirdashti et al. 2015) actually reduce non-renewable external energy inputs, improve efficiency, and maintain the capacity to generate ecosystemic services (Guzmán and González 2015).

Cacao is a crop of worldwide interest because it is the main raw material for the elaboration of chocolate and other byproducts. Different studies have measured the environmental impact of cacao/chocolate from a life cycle approach. For instance, Ntiamoah and Afrane (2008) studied cacao production and processing in Ghana, while Jungbluth and König (2014) analyzed the life cycle of different types of chocolate and showed how the subphase of cacao production concentrates, approximately, $70 \%$ of the total non-renewable energy consumption. Ecuador is the sixth largest cacao producer in the world (4.9\% of the total tons) and the first producer of cacao Fino de Aroma (fine aroma) (ICCO 2014). Even though cacao, in Ecuador, is one of the most important crops in terms of territory ( $9 \%$ of the cultivated area), economy ( $0.56 \%$ of the GDP), and employment ( $4 \%$ of the active population) (ProEcuador 2013), energy and techno-economic analyses at a farm level are rare. Pérez Neira (2016) analyzed the life cycle of cacao/chocolate in terms of energy differentiating the impact of cacao traditional and technified productions. Pino et al. (2013) studied the economic profitability of cacao in the province of Guayas and provided aggregated values by municipality.

Despite these important precedents, there is a lack of scientific information in Ecuador regarding the energy and economic performance of cacao in relation to the diversity of production management systems in this territory, and, particularly, about organic management as a more energysustainable alternative to the semi-intensification and technification of traditional management. Studies like that of Infante-Amate and Picado (2016) on the production of coffee in Costa Rica have shown how, for other tropical crops, industrialization has led to a very important drop in all energy efficiency indicators studied by the authors. Muner et al. (2015) provided empirical evidence of how the organic production of coffee in the state of Espírito Santo (Brazil) has allowed improving energy efficiency (metabolizable energy of coffee pulp $\times$ non-renewable input ${ }^{-1}$ ), as opposed to other production alternatives. In the case of Ecuador, there are no statistical data available that can help differentiate organic production from other forms of management. However, it is possible to observe a process of intensification in the crop's production that is reflected in an important increase of productivity per hectare (INEC 2014). In this sense, the comparative analysis of the energetic and economic behavior of agriculture as a function of the different types of production management provides relevant information that, keeping the limits of the study and the methodology in mind (Plevin and Delucchi 2014), can contribute to technical, economical, and political decision-making processes especially, in a global context defined by oil depletion and climate change (Murray and King 2012) and, most particularly, within a political framework as that of Ecuador, a country that is constitutionally committed to food sovereignty.

This work identifies four types of production management in the province of Guayas (Ecuador): (a) traditional (or peasant), (b) semi-intensive, (c) technified, and (d) organic. This province concentrates $22.5 \%$ of the cultivation area and $36 \%$ of the national production of cacao (INEC 2014). Taking as reference the reviewed literature on the topic, three hypotheses have been set up for this work: (1) the intensification of production, despite increasing crop profitability, causes a decrease in energy efficiency (EROI-energy return on the investment - and non-renewable external EROI) in comparison with traditional managements; (2) organic cacao production increases traditional and technified crop profitability and improves their energy efficiency; and (3) diversification of production is a strategy that allows improving both the incomes and the energy performance of small cacao farms. Consequently, and with the purpose of verifying these hypotheses, the following objectives have been defined: (1) to analyze the energy efficiency and dependence of the cacao production according to the different types of management, especially in relation to the use of non-renewable energy; (2) to evaluate the economic profitability of cacao; and (3) to identify the critical points of the energy and economic performance of cacao production depending on the production management system.

\section{Materials and methods}

\subsection{Sample selection, inventory elaboration, and techno-economic characterization of the sample}

First of all, the prevailing types of technical and production management in the study area were identified. There were four of them: (a) traditional (or peasant), (b) semi-intensive, (c) technified, and (d) organic. Traditionally managed farms are characterized by being agroforestry systems (where cacao coexists with dozens of other species) with low levels of input (and capital) use and usage of traditional (national) varieties of cacao associated with other crops (Fig. 1). Farms with semi-intensive management are traditional farms that have opted for the following: (1) the introduction of improved varieties (CCN51 or improved national clones), (2) augmenting fertilization doses, and/or (3) technified irrigation with the purpose of increasing the yield per hectare in agroforestry systems. Farms with technified management are monoculture production systems with a high degree of intensification in relation to other systems (improved varieties, high fertilization doses, 
Fig. 1 a Cacao monoculture production system, $\mathbf{b}$ cacao agroforestry production system, c CCN51 improved cacao variety, and d Nacional Fino de Aroma cacao variety
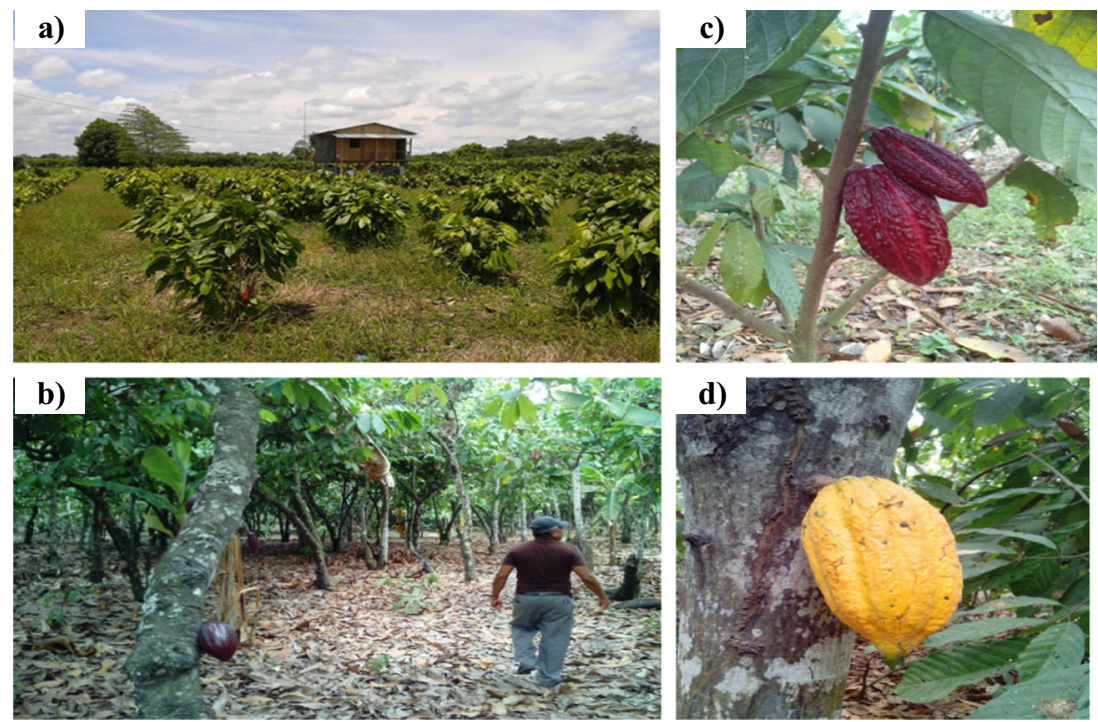

and technified irrigation). Farms with organic management are agroforestry systems with a high degree of diversification and no use of synthetic compounds, such as fertilizers or pesticides, and which have opted for the following: (1) technified irrigation and/or (2) the ecological and cultural intensification of management (high doses of organic fertilization, mechanic undergrowth control, cob collection, regular pruning for maintenance and formation, and the use of improved national varieties) with the purpose of also improving their yield per hectare.

After the previous technical and production-related characterization, 43 farms were selected to obtain non-statistical representation of the different types of management. For the selection of the sample, farms providing reliable information and implementing a good production management system were preferably identified, especially in the case of organic and technified farms. The farms were selected with the help of field technicians working for cacao cooperatives, the Department of Agriculture, Livestock, Aquaculture and Fishing of Ecuador in Guayaquil, and the Biotechnology Research Centre of Ecuador (CIBE). Four subsamples were thus configured, each of them with the following characteristics: (a) subsample 1 (traditional management): 10 farms analyzed ( $30.0 \mathrm{ha}$ ), $95 \%$ of national cacao and $5 \%$ of improved cacao varieties (CCN51), $100 \%$ of non-technified irrigation, and $50 \%$ of co-products sale (from the agroforestry system); (b) subsample 2 (semi-intensive management): 13 farms analyzed (78.8 ha), $75 \%$ of CCN51 and $25 \%$ of national cacao, $46.2 \%$ of technified irrigation and $53.8 \%$ of non-technified irrigation, and $7.7 \%$ of co-products sale; (c) subsample 3 (technified management): 10 farms analyzed (73.8 ha), $90 \%$ of CCN51 and $10 \%$ of improved national clones, $90 \%$ of technified irrigation and $10 \%$ of non-technified irrigation, and no co-products sale; and (d) subsample 4 (organic management): 10 farms analyzed (50.5 ha), $90 \%$ of national cacao and improved national cacao and $10 \%$ of CCN51, $40 \%$ of technified irrigation and $60 \%$ of non-technified irrigation, and $80 \%$ of co-products sale. Quantitative data were gathered through "face-to-face" questionnaires in the period between October 2014 and June 2015. These data were checked against the information available from cacao cooperatives (inputs purchase and cacao sale) and from other primary sources (technicians, other cooperative members, and cacao middlemen). The data were analyzed using SPSS software, version 21. The Lilliefors normality test rejected the null hypothesis according to which the data come from a normally distributed population ( $p$ value $<0.05$ ). Therefore, non-parametric tests for independent samples were performed, the Kruskal-Wallis $\mathrm{H}$ test to compare the four types of management and the Mann-Whitney $U$ test to analyze the samples in pairs (Wayne 1990). The $p$ values were adjusted by applying the Benjamini and Hochberg (1995) method, using the p.adjust function from the stats library of R statistical software, version 3.3.0 (R-Core Team 2016). The significance levels of difference were set at $p<0.05$.

\subsection{Functional unit, system boundary, and energy analysis}

The functional units of this work are the energy and economic performance of 1 cacao-producing hectare and the production of $1 \mathrm{~kg}$ of dried cacao (approx. $8 \%$ humidity), analyzed on the basis of four study levels (adapted from Pérez Neira et al. 2013). Level 1 measures the output in terms of commercialized agrarian production as shown in Eq. 1. Level 2 quantifies the energy consumed directly at the farm (direct energy), which includes organic fertilization, labor, diesel, and electricity. Levels 3 and 4 quantify the consumption of indirect energy (outside the farm). Level 3 reflects the energy cost of producing the inputs used during the production process (NPK fertilizers, crop 
protection, diesel, oil, electricity, and tools), while level 4 reflects the energy amortization of the technified irrigation system. The energy input has been estimated from Eq. 2 .

Total energy output $=\sum$ Dry cacao $\left(\mathrm{kg} \mathrm{ha}^{-1}\right)$

$$
\begin{aligned}
& \times \alpha_{(\mathrm{c})}\left(\mathrm{MJ} \mathrm{kg}^{-1}\right) \\
& +\sum \text { Other outputs }_{(\mathrm{i})}\left(\mathrm{kg} \mathrm{ha}^{-1}\right) \\
& \times \alpha_{(\mathrm{i})}\left(\mathrm{MJ} \mathrm{kg}^{-1}\right)
\end{aligned}
$$

where $\alpha_{(\mathrm{c})}$ : dry cacao energy coefficient, i: output $i$ (banana, pacay, sapote...), $\alpha_{(\mathrm{i})}$ : output energy coefficient of $i, \alpha_{(\mathrm{c})}$ and $\alpha_{(\mathrm{i})}$ represent the metabolizable energy of food.

$$
\begin{aligned}
\text { Total energy input } & =\sum \operatorname{Input}_{(\mathrm{j})}\left(\text { unit ha }^{-1}\right) \\
& \times \beta_{(\mathrm{j})}\left(\text { MJ unit }^{-1}\right)
\end{aligned}
$$

where $\mathrm{j}$ : input $j$ (N-P-K, organic fertilization, crop protection...), $\beta_{(\mathrm{j})}$ : input energy coefficient of $j$. Human labor $\left(\mathrm{h} \mathrm{ha}^{-1}\right)$ is calculated in relation to the direct energy expenditure (muscular power) associated with production tasks, on the basis of the estimated power rating of human labor $\left(\mathrm{MJ} \mathrm{h}^{-1}\right)$. Tools $\left(\mathrm{kg} \mathrm{ha}^{-1}\right)$, lubricants $\left(\mathrm{kg} \mathrm{ha}^{-1}\right)$, fertilizers $\left(\mathrm{kg} \mathrm{NPK} \mathrm{ha}{ }^{-1}\right.$ ), herbicides-pesticides ( $\mathrm{kg}$ active ingredient $\mathrm{ha}^{-1}$ ), and organic crop protection $\left(\mathrm{kg} \mathrm{ha}^{-1}\right)$ are calculated on the basis of the energy cost of producing the amount of material used in the farm $\left(\mathrm{MJ} \mathrm{kg}^{-1}\right)$. Organic fertilization $\left(\mathrm{kg} \mathrm{ha}^{-1}\right)$ is calculated from the energy content of the organic matter incorporated $\left(\mathrm{MJ} \mathrm{kg}^{-1}\right)$. Electrical energy $\left(\mathrm{kWh} \mathrm{ha}^{-1}\right)$ is calculated in relation to the total embodied energy by consumer, which includes the direct energy requirements of power generation and grid losses $\left(\mathrm{MJ} \mathrm{kWh}^{-1}\right)$. Diesel $\left(\mathrm{kg} \mathrm{ha}^{-1}\right)$ is calculated according to the energy contents of fuel and its energy cost of production $\left(\mathrm{MJ} \mathrm{kg}^{-1}\right)$. Irrigation machinery and infrastructure $\left(\mathrm{kg} \mathrm{ha}^{-1}\right.$ and $\mathrm{m}^{3} \mathrm{ha}^{-1}$ in the case of concrete) are calculated on the basis of the energy cost of production by weight/volume (adapted from Pérez Neira 2016) and the following amortization assumptions: water pump and concrete (pivot sprinklers), 12 years and piping, 5 years, and sprinklers, 3 years.

The coefficients selected in order to measure the inputs are a key factor in energy analyses because they significantly influence the results obtained, but they are not always well defined (Frischknecht et al. 2015). In this sense, the work by Aguilera et al. (2015) has been taken as reference for the assessment of the main cacao inputs (infrastructure, NPK fertilizers, the active ingredients of herbicides and fungicides, and diesel). After making a thorough literature review and presenting its own estimates, Aguilera et al. (2015) provided a coherent database that included the direct and/or indirect energy of the main agrarian inputs at the maximum disaggregation level available. Pointing in the same direction, Pérez Neira et al. (2013) provided coefficients for organic crops fertilization and protection, labor, oil, tools, and electricity-value adapted from MCSE (2013). Neither capital nor the energy cost of transporting agrarian inputs from the factories to the farm has been considered due to the lack of reliable information. The coefficients used to define the energy output of (dry) cacao, pagay (Inga feuilleei), sapote (Pouteria sapota), citrus fruits, mangoes, and avocado are the following: 19.0, 2.7, 2.3, 1.5, 1.6, and $5.7 \mathrm{MJ} \mathrm{kg}^{-1}$, respectively (adapted from Pérez Neira 2016 and the nutrition study by Moreiras et al. 2005).

\subsection{Economic and energy indicators}

For the economic analysis, the cost and income structure of the farms has been calculated, as well as their net margin per hectare (incomes minus total costs, including taxes and amortization of capital). As in the energy analysis, the total income is the result of adding up all incomes derived from the sale of cacao and other products. For the energy analysis, three synthetic indicators have been selected, they are specified in the following three equations $(3,4$, and 5$)$ :

Energy return on the investment (EROI)

$$
\begin{aligned}
= & \text { total energy output }\left(\mathrm{MJ} \mathrm{ha}^{-1}\right) \\
& \times \text { total energy inputs }^{-1}\left(\mathrm{MJ} \mathrm{ha}^{-1}\right)
\end{aligned}
$$

Non-renewable external EROI

$$
\begin{aligned}
&= \text { totalenergy output }\left(\mathrm{MJ} \mathrm{ha}^{-1}\right) \\
& \times \text { non-renewable external inputs } \\
&-1 \\
&\left(\mathrm{MJ} \mathrm{ha}^{-1}\right)
\end{aligned}
$$

Non-renewable energy intensity $=$ net $\operatorname{margin}\left(\$ \mathrm{ha}^{-1}\right)$

$$
\times \text { non-renewable external inputs }{ }^{-1}\left(\mathrm{MJ} \mathrm{ha}^{-1}\right)
$$

where non-renewable external input $=$ total energy input $\left(\mathrm{MJ} \mathrm{ha}^{-1}\right)$ - renewable energy input $\left(\mathrm{MJ} \mathrm{ha}^{-1}\right)$.

EROI allows estimating the return of the energy that is intentionally invested by society in agrarian systems (Guzmán and González 2015), particularly the energy efficiency of cacao production (and of its associated crops) (see the limits of the study, section 2.4). Non-renewable external EROI emphasizes the dependence on inputs brought from outside the agrarian system (Tello et al. 2016) in relation to the use of non-renewable energy. This indicator is especially relevant in the current context of global energy crisis and high dependence on external inputs in agriculture. Non-renewable energy intensity allows analyzing the capacity that agriculture has to generate value added in relation to the consumption of 
non-renewable energy. In order to estimate indicators 4 and 5 , the total energy input is also classified into renewable and non-renewable forms (Pirdashti et al. 2015). Renewable energy includes labor, organic fertilization (from outside/inside the farm), and the proportional share of renewable energy (mainly wind, hydraulic, and solar) used in the production of agrarian inputs, estimated on the basis of the information provided by Aguilera et al. (2015) and the Coordinating Ministry of Strategic Sectors (MCSE 2013).

\subsection{Limits of the study and future prospects}

Given the socioeconomic and energy approach of this work, the following items have not been considered: the family consumption of products obtained from the agroforestry system (cacao, wood, and other foodstuffs), the non-monetarized exchanges within family or neighbor networks, and the reuse for animal feed (hens, pigs, etc.). In the economic analysis, the value of the land or the financial accounting of the farms have not been included, as in previous cases, because of the lack of reliable information on the matter. It was decided to make a sensible downward estimate of the economic/energy efficiency of cacao systems, especially in the case of agroforestry systems. The present analysis could be complemented by using other approaches and indicators (Tello et al. 2016) paying greater attention to ecosystemic processes (Guzmán and González de Molina 2015). It would be necessary to make an estimate of the net primary production by analyzing, in addition to external inputs and the social use of energy (sales, family consumption, etc.). The flows of biomass recycled and reused inside the agroecosystem can become, as in the case of coffee agroforestry systems, the most important flows in terms of energy and nutrients (Infante Amate and Picado 2016). On the other hand, it is necessary to acknowledge the limits inherent to the exclusive use of monetary and energy indicators, as well as the need to further deepen environmental analyses. On the basis of a comparative study of 65 research works, Huijbregts et al. (2010) state that the analysis of the energy demand is generally considered less relevant than that of other impacts in the case of agricultural products. Therefore, focusing the analysis on the energy demand may be concealing the shifting of other environmental burdens (for instance, farms with lower yields need a larger area to produce the same amount and changes in the use of the land may cause a loss of biodiversity and an increase of greenhouse gas emissions). In this sense, all empirical, methodological, and conceptual limitations must be taken into account when interpreting and using the results, especially in political decision-making (see Plevin and Delucchi 2014). In addition, these limitations and contributions will allow opening new research lines to complement and further explain the results obtained in the present research.

\section{Results and discussion}

\subsection{Energy and monetary input, output, and indicators of cacao}

On average, the total energy input of cacao production was estimated at 2.94, 9.59, 18.85, and $7.50 \mathrm{GJ} \mathrm{ha}^{-1}$ for traditional, semi-intensive, technified, and organic farms (Table 1). Irrigation (which includes infrastructure, diesel, oil, and electricity) is the most important energy input in farms with technified $(68.9 \%)$, semi-intensive $(62.3 \%)$, and organic managements $(54.7 \%)$ and the second most important one for traditional management $(22.5 \%)$. Non-organic fertilization and synthetic pesticides are the main energy input in traditional farms $(44.5 \%)$, and the second one in semiintensive $(26.1 \%)$ and technified $(25.5 \%)$ farms. In addition, organic fertilization is the second most important input in organic farms $(32.8 \%)$ and represents 16.2, 5.5, and 3.2 \% of the total energy input in traditional, semi-intensive, and technified farms. The remaining inputs represent between 2.3 and $14.3 \%$ of the total energy input depending on the type of production management. With the exception of traditional farms $(11.7 \%)$, labor accounts for 1.5 to $4.6 \%$ of the total energy consumption. Non-renewable external inputs represent between 65.2 and $82.9 \%$ of the total energy input for all types of management except organic $(58.9 \%)$.

The non-renewable external inputs of cacao production were estimated at $7.40,14.32,14.66$, and $7.27 \mathrm{MJ} \mathrm{kg}^{-1}$ for traditional, semi-intensive, technified, and organic managements (Table 2). Cacao energy production was estimated at $8.13,14.59,26.55$, and $19.18 \mathrm{GJ} \mathrm{ha}^{-1}$ for traditional, semiintensive, technified, and organic managements. With regards to the energy production associated with the sales of other crops, the output estimation is increased by 152 and $129 \%$ in traditional and organic farms. Semi-intensive farms barely sell co-products, while technified farms are monocultures by definition. On average, traditional farms turned out to be the most efficient ones in terms of total energy use with an EROI of $1: 1.98$, compared to $1: 1.22,1: 1.44$, and 1:1.81 for farms with technified, semi-intensive, and organic management (non-significant results). Organic (1:3.07) and traditional (1:2.93) farms are more efficient than semi-intensive (1:1.85) and technified (1:1.47) farms in terms of non-renewable external EROI (significant results). Adapting the functional unit, Pérez Neira (2016) produces results for the same indicator that are coherent with this work: 1:1.45 and 1:2.02 for technified and traditional cacao production in Guayas.

The total costs of cacao production were estimated at $\$ 274, \$ 897, \$ 1424$, and $\$ 752 \mathrm{ha}^{-1}$ for farms with traditional, semi-intensive, technified, and organic managements (Table 1). Labor wages are the most important monetary expenditure in all four types of management representing between 35.0 and $56.3 \%$ of the total 


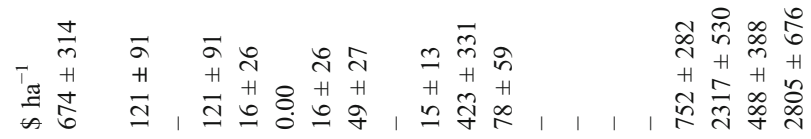

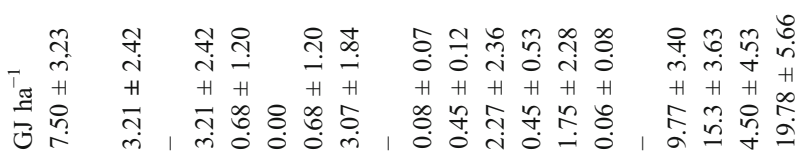

T)

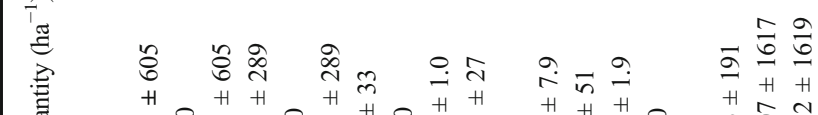

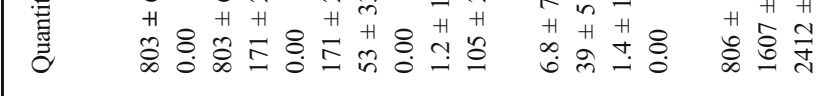

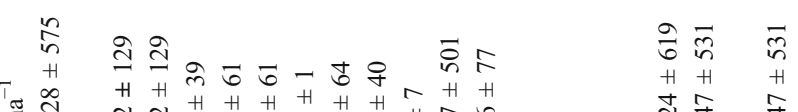

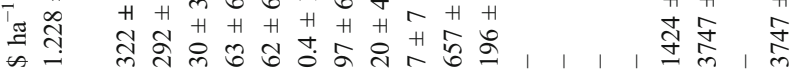

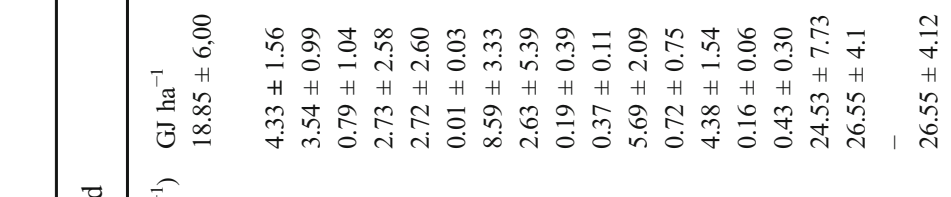

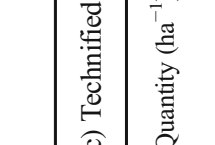

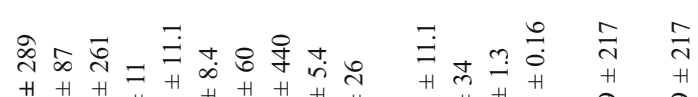

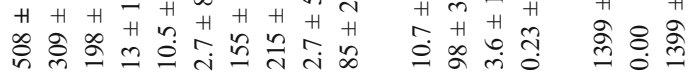

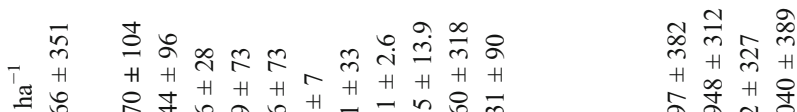

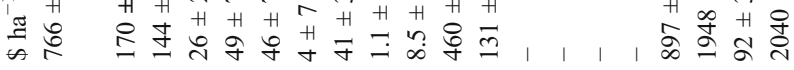

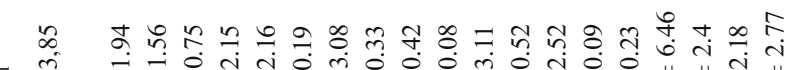

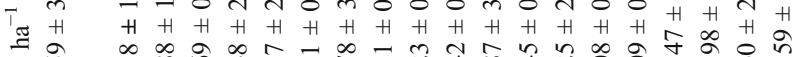

露 T

ध

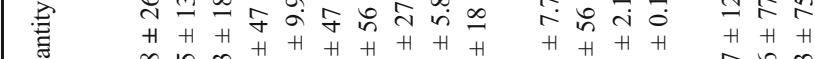

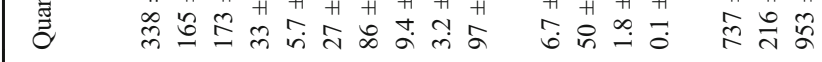

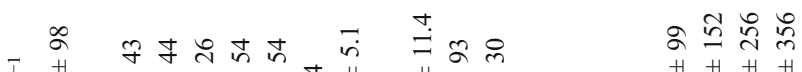

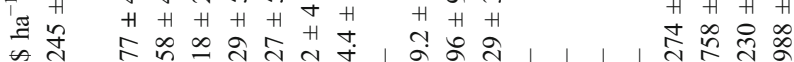

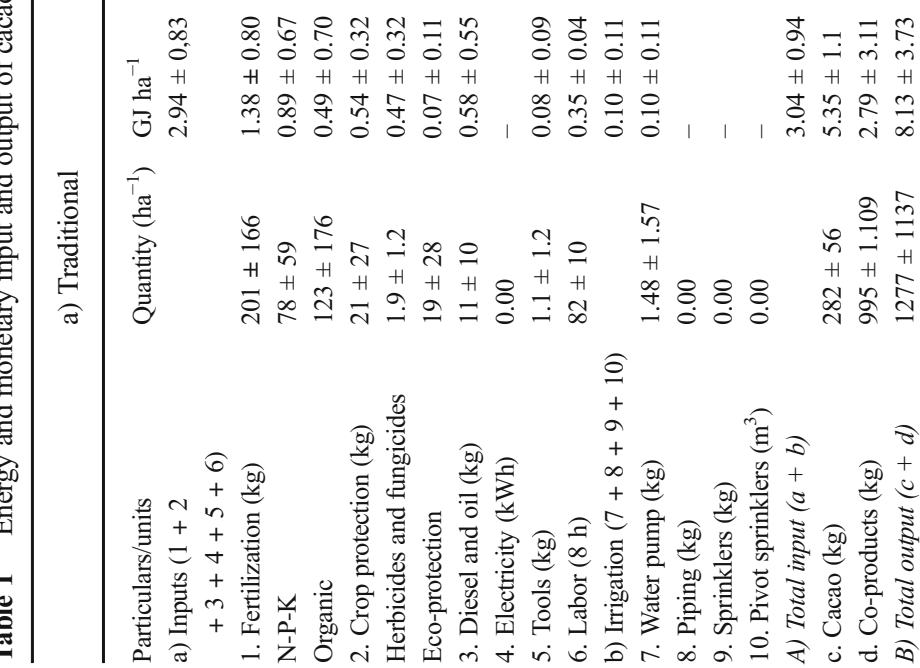

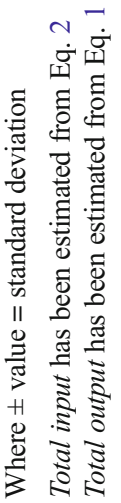


production costs. Fertilization is the second monetary expenditure in importance (16.1 to $28.0 \%$ ) followed by amortizations (10.4 to $14.6 \%)$ and tools $(0.5$ to $3.3 \%)$. Energy (diesel plus electricity) expenses represent $8.2 \%$ of the total cost in technified farms and 1.6, 4.7, and $6.6 \%$ in traditional, semi-intensive, and organic farms. Regarding the monetary output, average incomes associated with cacao were estimated at $\$ 758, \$ 1948, \$ 3747$, and $\$ 2317 \mathrm{ha}^{-1}$ for the four analyzed types of management, and there are additional incomes of $\$ 230$ and $\$ 488 \mathrm{ha}^{-1}$ derived from co-product sales for farms with traditional and organic management systems (with high levels of dispersion, due to the fact that only a percentage of farms actually sell other products). For the province of Guayas, Pino et al. (2013) estimated an average net margin of $\$ 466$ to $\$ 969 \mathrm{ha}^{-1}$ depending on the municipality. The results from this work show how cacao profitability is clearly influenced by the production management system. Technified management gets the best results in terms of net margin per hectare: $\$ 2323$ as compared to $\$ 484$, $\$ 1051$, and $\$ 1565 \mathrm{ha}^{-1}$ for farms with traditional, semiintensive, and organic management (significant results). Differing from energy results, the high yields obtained in technified farms allow compensating, given the market prices of reference, increases in the production cost. The same pattern is found in farms with semi-intensive management, where higher productivity per hectare associated to the use of improved varieties allows multiplying the net margin of traditional farms by 2.17 , despite their higher production costs ( $\$ 897$ compared to $\$ 274 \mathrm{ha}^{-1}$ ).

Organic management yields better results than traditional and semi-intensive managements. Organic intensification associated with fertilization dose increase and greater performance of cultural labors and the use, to a great extent, of more productive national varieties allow yields per hectare that are similar or slightly higher than those of semi-intensive farms (806 compared to $737 \mathrm{~kg} \mathrm{ha}^{-1}$ ). Consequently, the greater profitability of organic farms is explained by the overpricing placed on organic cacao: $2.90( \pm 0.24)$ compared to $\$ 2.67 \mathrm{~kg}^{-1}$ $( \pm 0.08)$ for conventional cacao. Traditionally managed farms produced the worst results with a net margin of $\$ 484 \mathrm{ha}^{-1}$, mainly due to low production per hectare and market prices that are not variety-differentiated ("national fine aroma" cacao and CCN51). The non-renewable energy intensity of traditional, semi-intensive, technified, and organic farms was estimated at $0.27 ; 0.15 ; 0.14$, and $\$ 0.31 \mathrm{MJ}^{-1}$. These data show the greater capacity of traditional and organic farms to generate net margin in relation to non-renewable energy consumption. With regards to the co-production associated with cacao agroforestry systems, all indicators improve for traditional and organic farms, reaching values of 1:4.26 and 1:3.80 for nonrenewable external EROI and \$714 and \$2053 ha ${ }^{-1}$ for net margin. Traditional and organic farms multiply by a factor of 
2.90 and 2.59, respectively, the efficiency (non-renewable external EROI) of technified farms when co-production is taken into account.

\subsection{Energy sustainability and economic profitability of cacao production as a function of the production management system}

The economic analysis of cacao production shows how technification and semi-intensification allow obtaining a higher net margin than traditional production multiplying it by 4.8 and 2.2. The results show how technified management is the best strategy to increase profitability per hectare. Income increase via productivity compensates for increments on the production costs associated with technified management. Nevertheless, the results of the energy analysis show as well how technification significantly diminishes the crop's nonrenewable EROI, partially validating the first hypothesis of this work. In terms of energy and for other tropical crops like coffee, Infante-Amate and Picado (Infante Amate and Picado 2016) analyzed how, between 1935 and 2010, the industrialization of agroforestry systems led to a very important drop in all the energy efficiency indicators analyzed, including those that are equivalent to the ones used in this work. In the case of Ecuador, Pérez Neira (2016) showed how the increment of productivity does not compensate the increase in the use of non-renewable energy, causing a loss of efficiency in comparison with traditional managements. As proved by the data gathered for this work, this result may also be applied to the semi-intensification strategy of cacao production. While semi-intensive and technified farms multiply yields $\left(\mathrm{kg} \mathrm{ha}^{-1}\right)$ by a factor of 2.61 and 4.96 in relation to traditional farms, non-renewable external inputs do so by factors of 5.06 and 9.83 per hectare. Consequently, the non-renewable external input $\left(\mathrm{MJ} \mathrm{kg}^{-1}\right)$ of semi-intensive and technified farms is approximately 1.96 greater than that of traditionally managed farms.

Likewise, the energy analysis shows how well-managed organic farms allow reducing the dependence on nonrenewable external inputs $\left(7.27 \mathrm{MJ} \mathrm{kg}^{-1}\right)$ as compared with semi-intensive and technified managements (14.32 and $14.66 \mathrm{MJ} \mathrm{kg}^{-1}$ ) (significant results). Therefore, the energy efficiency of organic production significantly increases, multiplying non-renewable external EROI by 1.66 and 2.09. These results are in consonance with those of other works that have performed comparative analyses on the energy dependence and efficiency of organic and conventional productions. After reviewing 50 scientific studies, Smith et al. (2015) showed how, for almost all crops, with only some exceptions, organic production uses less fossil energy per land unit, the results per product unit being more variable (due to the lower yields in most organic crops). Taking again the example of coffee, Muner et al. (2015) estimated energy efficiency (metabolizable energy of coffee pulp $\times$ non-renewable input ${ }^{-1}$ ) use and concluded that it is six times greater for organic farms than it is for conventional farms in the state of Espírito Santo (Brazil). On the other hand, the economic analysis shows how organic management allows obtaining a net margin that is higher $(49 \%)$ than that of semi-intensive management, but lower (32\%) than the one achieved in technified farms. These results partially validate the second hypothesis formulated in this work: even though organic management yields better economic results than semi-intensive management, the same does not apply with respect to technified management.

In terms of energy sustainability, organically and traditionally managed cacao agroforestry systems are the ones less dependent on non-renewable energy consumption and more efficient in energy use, a result that supports other studies that highlight the potential of traditional and organic agriculture in the construction of sustainable productive alternatives (FunesMonzote 2009; Altieri et al. 2011). Furthermore, traditional and organic farms are, in fact, the ones supporting production diversification and co-product sales. This strategy not only raises the families' degree of food autonomy (as well as that of the neighbor network, through non-monetary exchanges), but also improves the energy and economic efficiency of cacao farms. In the case of traditional and organic farms, coproduct sales multiply the net margin per hectare by 1.47 and 1.31, and the non-renewable external EROI by 1.45 and 1.24. When co-products are taken into account, there is no significant difference in income per hectare between organic and technified farms, as opposed to when only cacao is considered. This result partially validates as well as the third hypothesis because this is not the case in traditional farms. Farms with semi-intensive management systems also diversify their production, but cannot access the market in the same way, which means a loss of additional incomes.

In summary, despite the limited scientific information on the energy and economic performance of cacao in Ecuador in relation to the type of production management, this work proves how, in the present case study, the technification and semi-intensification of the traditional management system increment the crop's profitability and energy dependence (non-renewable external inputs) while reducing its non-renewable external EROI. Traditionally managed farms, despite having lower profitability per hectare, are more sustainable in terms of energy than those intensively managed. Well-managed organic farms improve economic results in relation to traditional and semiintensive managements, and non-renewable energy results in relation to semi-intensive and technified managements. Additionally, the present research provides novel information about the importance of diversification as a production strategy that allows increasing the incomes and energy 
efficiency of small cacao producers at the farm level. This strategy is, however, barely used by most farmers.

\section{Conclusions}

In the present work, a case study of the province of Guayas (Ecuador), novel information about the energy and economic performance of cacao production as a function of the type of production management is presented. Technified irrigation (infrastructure and energy), fertilization, and crop protection are the most important energy inputs in all four types of management, while labor and fertilization are the most relevant ones in monetary terms. Technified monoculture is the best strategy to increment the net margin per hectare. However, this increment in profitability takes place at the expense of greater dependence on non-renewable energy associated with a greater use of fertilizers, fossil fuel, and capital (irrigation). This way, traditional cacao farms multiply by 1.59 and 2.00 their efficiency in relation to non-renewable external EROI as compared to technified and semi-intensive farms, but their economic profitability is much lower (484 in contrast with $\$ 1051$ and $\$ 2323 \mathrm{ha}^{-1}$ ).

On the other hand, the data show how well-managed organic farms increase profitability in relation to traditional and semi-intensive agriculture. Economic improvements are related to yields, which are comparable to those of semi-intensive farms, and to the access to differentiated markets that provide an overprice to organic cacao. Similarly, organic management improves by 139 and $152 \%$ the non-renewable external EROI of semi-intensive and technified productions. Moreover, the results also indicate how the production diversification of cacao farms and their access to markets are key elements to increase and diversify the incomes of small-scale farmers, while contributing to the improvement of energy efficiency indicators in cacao farms. In the case of organic farms, a proper management and economic exploitation of the co-products may provide high earnings, with no significant differences in comparison to technified farms.

The results of this research include new theoretical elements and empirical data that allow improving current knowledge on the economic and energy performance of cacao production in Ecuador according to production and management differences. Without losing sight of the limits of this work, the results provide relevant information to be taken into account when making technical, economical, and political decisions aiming for sustainability in consonance with the principles of Food Sovereignty of the Ecuadorian Constitution. Additionally, it would be necessary to continue researching on the energy and economic performance of cacao to further deepen the analysis of the energy sustainability of cacao production, as well as to confront the limits and develop the future research prospects set up by this work.
Acknowledgments This work is part of a project titled "Moving towards food sovereignty: socioeconomic and environmental analysis of the agrifood system of cacao production in the Guayas province (Ecuador). An approximation from socio-environmental complexity," as a part of the Prometeo Project of the National Secretary for Higher Education, Science, Technology and Innovation (SENESCYT) of the Republic of Ecuador. The author would like to thank the farmers, the cacao cooperatives, and the Ecuadorian Center for Biotechnology Research (CIBE) for their cooperation. Likewise, we would like to thank Ramón Álvarez Esteban (Universidad de León) for his help in the statistical analyses.

\section{References}

Aguilera E, Guzmán G, Infante-Amate J, Soto D, García-Ruiz R, Herrera A, Villa I, Torremocha E, Carranza G, Gonzáles de Molina M (2015) Embodied energy in agricultural inputs. Incorporating a historical perspective. DT-SEHA 15-07. Available online at http://repositori. uji.es/xmlui/bitstream/handle/10234/141278/DT-SEHA\%201507. pdf? sequence=. Accessed 26 Apr 2016.

Altieri MA, Funes Monzote F, Petersen P (2011) Agroecologically efficient agricultural systems for smallholder farmers: contributions to food sovereignty. Agron Sustain Dev 32(1):1-13. doi:10.1007/s13593-011-0065-6

Arizpe N, Giampietro M, Ramos-Martin J (2011) Food security and fossil fuel 21 dependence: an international comparison of the use of fossil energy in agriculture (1991- 2003). Crc Cr Rev Plant Sci 30:45-63. doi:10.1080/07352689.2011.554352

Benjamini Y, Hochberg Y (1995) Controlling the false discovery rate: a practical and powerful approach to multiple testing. J R Stat Soc Ser B Methodol 57:289-300. doi:10.2307/2346101

Frischknecht R, Wyss F, Knöpfel S, Lützkendorf T, Balouktsi M (2015) Cumulative energy demand in LCA: the energy harvested approach. Int J Life Cycle Assess 20(7):957-969. doi:10.1007/s11367-016-1073-1

Funes-Monzote FR (2009) Agricultura con futuro: la alternativa agroecológica Para Cuba. Estación Experimental Indio Hatuey, Matanzas

Gliessman SR (1998) Agroecology: ecological process in sustainable agriculture. Ann Arbor Press, Ann Arbor

Guzmán G, González de Molina M (2015) Energy efficiency in agrarian systems from an agroecological perspective. Agroecol Sust Food 39:924-952. doi:10.1080/21683565.2015.1053587

Huijbregts MAJ, Hellweg S, Frischknecht R, Hendriks HWM, Hungerbu $\mathrm{K}$, Hendriks AJ (2010) Cumulative energy demand as predictor for the environmental burden of commodity production. Environ Sci Technol 44(6):2189-2196. doi:10.1021/es902870s

ICCO (2014) Production of cacoa beans. Quarterly bulletin of cacoa statistics, Vol XL, N 4, Cacoa year 2013/14.

INEC (2014) Encuesta de Superficie y Producción Agropecuaria Continua. Instituto Nacional de Estadística y Censos (INEC) (Ecuador). Available online at http://www.ecuadorencifras.gob.ec/encuesta-deproduccion-agropecuaria-continua/. Accessed 28 Apr 2016.

Infante Amate J, Picado W (2016) Socio-ecological transition on costarrican coffe agro-ecosystems. Energy flows material flows and time use (1935-2010). Old and new worlds: The global challengers of rural history, Lisbon, 27-20 Junary.

Jungbluth N, König A (2014) Environmental impacts of chocolate in a life cycle perspective. ESU-services Ltd. Available online at http://www.esu-services.ch/fileadmin/download/jungbluth-2014 LCA_chocolate.pdf. Accessed 10 Apr 2015.

Leach G (1976) Energy and food production. IPC Science and Technology Press, London

MCSE (2013) Balance Energético Nacional. Series Históricas 1995-2012. Ministerio Coordinador de Sectores Estratégicos (MCSE). Available online at http://www.sectoresestrategicos.gob.ec. Accessed 1 Apr 2015. 
Moreiras O, Carbajal A, Cabrera L, Cuadrado C (2005) Tablas de composición de alimentos. Ediciones Pirámide, Madrid

Muner LHD, Masera O, Fornazier MJ, Souza CVD, de Loreto MDD (2015) Energetic sustainability of three arabica coffee growing systems used by family farming units in Espírito Santo state. Engenharia Agrícola 35(3):397-405

Murray J, King D (2012) Climate policy: oil's tipping point has passed. Nature 481:433-435. doi:10.1038/481433a

Ntiamoah A, Afrane G (2008) Environmental impacts of cocoa production and processing in Ghana: life cycle assessment approach. J Clean Prod 16:1735-1740. doi:10.1016/j. jclepro.2007.11.004

Pérez Neira D (2016) Energy sustainability of Ecuadorian cacao export and its contribution to climate change. A case study through product life cycle assessment J Clean Prod 112: 2560-2568. doi 10.1016/j. jclepro.2015.11.003.

Pérez Neira D, Soler Montiel M, Simon Fernández X (2013) Energy analysis of organic farming in Andalusia (Spain). Agroecol Sust Food 37(2):231-256. doi:10.1080/10440046.2012.734263

Pirdashti H, Pirdashti M, Mohammadi M, Baigi MG, Movagharnejad M (2015) Efficient use of energy through organic rice - duck mutualism system. Agron Sustain Dev 35:1489-1497. doi:10.1007 /s13593-015-0311-4

Pimentel D (ed) (1980) Handbook of energy utilization in agriculture. CRC Press, Boca Raton FL
Pino S, Quinde V, Guamán V, Rodríguez H (2013) Diagnóstico Agroesocioeconómico en zonas cafetaleras y cacaoteras del Ecuador. Instituto de Investigación de Economía Agrícola y Desarrollor Rural (INEAR) y Universidad Agraria del Ecuador.

Plevin RJ, Delucchi M (2014) Using attributional life cycle assessment to estimate climate-change mitigation benefits misleads policy makers. J Ind Ecol 18(1):73-83. doi:10.1111/jiec.12074

ProEcuador (2013) Análisis sectorial de Cacao y sus Elaborados. Pro Ecuador. Instituto de Promoción de Exportaciones e Inversiones. Available online at http://www.proecuador.gob.ec. Accessed 30 Sept 2014.

R Core Team (2016) R: A language and environment for statistical computing. R Foundation for Statistical Computing, Vienna, Austria. URL https://www.R-project.org/.

Smith L, Williams A, Pearce B (2015) The energy efficiency of organic agriculture: a review. Renew Agr Food Syst 30(3):280-301. doi:10.1017/S1742170513000471

Tello E, Galán E, Sacristán V, Cunfer G, Guzmán GI, de Molina MG, Krausmann F, Gingrich S, Padró R, Marco I, Moreno-Delgado D (2016) Opening the black box of energy throughputs in farm systems: a decomposition analysis between the energy returns to external inputs, internal biomass reuses and total inputs consumed (the Vallès County, Catalonia, c. 1860 and 1999). Ecol Econ 121:160 174. doi:10.1016/j.ecolecon.2015.11.012

Wayne D (1990) Applied nonparametric statistics. PWS-KENT, Boston 